\title{
RUNSAS REPPU TYÖKALUJA
}

\author{
Ilpo Vuorinen (1998) \\ Tiimin rakentajan ja \\ työyhteisön kehittäjän \\ Resurssi-Reppu. \\ Resurssi.
}

Työyhteisön kehittäjien suulliseen perimätietoon kuuluva viisaus toteaa: työyhteisössä pitäisi olla niitä, jotka ajattelevat ja niitä, jotka tekevät; ihanteellista olisi, jos nämä ominaisuudet yhdistyisivät jokaisessa jäsenessä. Jos ResurssiRepun lukija on toiminnan ihmisiä, hän luultavasti ihastuu ja innostuu. Jos korostetusti ajatteluun keskittyvä lukee Resurssireppua, hän todennäköisesti pian hengästyy ja tulee ärtyneeksi.

\section{Reppu on tyypillistä}

"konsulttikirjallisuutta", ote on eklektinen ja kokemuksellinen, ajatusten esittäjiä ja taustoja ei paljonkaan selvitellä, viitekehys on luettava enemmänkin rivien väleistä. Vuorinen ilmentää omaa ammatillista kasvuaan mielikuvalla "Reppu ja reissumies". "Kutsumukseni on ollut kulkea yli rajojen ja koota reppuuni kaikkea osaamista, mitä eri puolilla suomalaista yhteiskuntaa - ja vähän kauempanakin - on työyhteisön kehittämisessä löydetty. Näiden kokemusten pohjalta olen ResurssiRepun materiaalin kehittänyt." Vuorisella oli keskeinen rooli rippikoulun uudistamisessa 1970-luvulla; hän kehitteli elämyksellisen aktivoinnin ja työskentelyn perinteisen opetuksen oheen ja rippikoulusta tuli kirkon ope- tuksen lippulaiva. Sittemmin hänesstä tuli yrittäjä: kouluttaja ja kehittäjä. 1990-luvulla ilmestyi menetelmäopas Tuhat tapaa opettaa; resurssireppu tuntuu sen laajennukselta yhteisöjen kehittämisen suuntaan. Vuorinen lähestyy kehittämistä koulutuksesta päin työskentelypaketin tarjouksella. Konsultin rooli jää kouluttajan roolin varjoon. Toisaalta tarjolla on tietynlainen strategia- ja suunnittelumalli.

\section{Esipuheen mukaan repun} stratregia-ajattelu perustuu EKS Finland Oy:n kehittämälle yrityksen koulutus- ja kehittämisstrategialle. Sen Yrittäjyyden yhteisö -prosessiohjelmia ja tukea suositetaan repputyöskentelyn tueksi. Tarjolla on "perusteellista koulutus- ja kehittämistukea niille, jotka haluavat syventää strategista näkemystään, työstää käytännössä oman kannattavimman etenemissuuntansa, rakentaa siihen läpimurtoprojektin, juurruttaa asiakkaalta ohjautuvan oppimisprosessin sekä luoda organisaatiostaan yrittäjyyden yhteisön ja jatkuvan innovaatiokehityksen yhteistyöympäristön." - Huh, huh.

\section{Yleisen strategia- ajattelun kannalta repun toimintaote näyttää liittyvän Petersin ja Watermanin lanseeraamaan "intohimo me- nestykseen" -strategiaan sekä uudempaan ydinpätevyys- ja osaaminen -strategiaan, jossa yhdistyy resurssiajattelu ja oppivan organisaation}

ihmiskeskeinen ajattelu. Strategian kaksi olennaista asiaa on vastata kysymyksiin: missä toimitaan? (asiakkaat, areenat, markkinat) ja miten toimitaan? (osaamis-, menestys- ja ylivoimatekijät). Rakenteissa pyritään mataliin organisaatioihin, itseohjautuviin työryhmiin, tiimeihin ja verkostoihin. (Kettunen 1997).

\section{Näistä lähtökohdista} nousee ensimmäisen kansion sisältö eli "perustehtävän tarkistaminen", mikä tarkoittaa "strategisen suunnittelun prosessia" lukuisine työskentelymalleineen. Toinen kansio ohjaa tiimin rakentamiseen, jälleen monin menetelmin ja välinein. Mukana on lisäksi kuvatauluja, kalvopohjia, korttipakka, tarroja ja lomakedisketti. Näin kangasrepun hinta 1.490 mk + alv käy ymmärrettäväksi.

\section{Viimeistään tässä}

vaiheessa on tarpeen kysyä, kenelle resurssireppu on tarkoitettu?; kuka on asiakas? Esipuheen mukaan tiimin ja työyhteisön johtajan tulisi nähdä itsensä oman yhteisönsä konsulttina, kehittäjänä ja valmentajana. Hänen ei itsensä tarvitse aina toimia kehittämistyön ohjaajana, mutta hänen on huolehdittava, että "työpaikalla on sijaa yhteisön sisäistä toimintaa koskeville keskusteluille. Sitä on työyhteisön kehittäminen "lyhyemmän kaavan mukaan", ja siihen ResurssiRepussa on eväitä." Myöhemmin todetaan, että materi- 
aali on suunniteltu ensisijaisesti niille, jotka haluavat käynnistää työyhteisön toimivuuteen liittyvää keskustelua, vaikka heillä ei olisikaan konsultin ammattitaitoa. He toimivat oikeastaan sisäisen konsultin roolissa. Yhteisön vuorovaikutuksen ja yhteistyön oletetaan silloin sujuvan kohtuullisesti. Ammattikonsultit työskennelkööt pitemmän kaavan mukaan ongelmatilanteissa ja yhteisöissä!

\section{Tältä taustalta on}

ymmärrettävissä amerikkalaismallisen tiukasti strukturoitu ja ohjaava työskentelyote. Se antaa turvallisuutta, rajaa kenttää ja on näennäisen helppoa. Pulmaksi voivat tulla ylenmäärin positiivisessa kulttuurissa kiellettyjen yhteisön ja jäsenten destruktiivisten puolien käsittely niiden mahdollisesti pulpahtaessa esiin. Yhteisön johtajan tai jäsenen tai tiimin vetäjän roolinvaihdot perustehtävästään sisäiseksi konsultiksi vaatii laajempaa ammatillista opiskelua ja tukea vaikkapa prosessikonsultilta. Tässä ollaan struktuurin ja prosessin suhteen klassisessa pulmassa. Struktuurilla voidaan rajata olennaisen vaikeita kysymyksiä pois käsittelystä. Materiaalilla on runsaasti käyttöä työyhteisökouluttajalle. Prosessikonsulttikin löytää sovellettavaa. Kummankin on tarpeen tehdä itselleen selväksi, mihin tarkoitukseen hän materiaalia käyttää.

\section{Repun markkinasivulla} asiakkaina nähdään kirkon ja seurakunnan työyhteisöt. Niille tarjotaan "uudenlaista asennoitumista työhön, lisää tietoisuutta kohderyhmäsuuntaiseen erikoistumiseen ja markkinaherkkään toimintaan sekä val- mennusta tiimien Toimintaan." Ydinosaamisesta asiakassuuntautuvan strategian soveltaminen seurakuntayhteisöön on kiintoisa ajatus. Perinteisesti on ajateltu, että seurakunnilla on julkisen sektorin tapaan teologisesta itseymmärryksestä/poliittisesta päätöksenteosta nousevat tehtävänsä. Osaamista on hankittu niiden suorittamiseen. Nyt halutaan tehdä, mitä parhaiten osataan ja mitä parhaiten ostetaan. Toisaalta repun työotteessa ei juuri näy esimerkiksi kirkon olemuksen ja tehtävän irrationaallisuus ja mysteeriluonne, niistä johtuvat individualistiset työnäyt, mutkikkaat rakenteelliset ratkaisut ja johtajuuspulmat. Kirkon omassa työyhteisöjen kehittämistoiminnassa on painiskeltu paljon niiden kanssa. Miten mahtanevat valtion, kunnan, yritysten, järjestöjen, oppilaitosten ym. yhteisöjen kehittäjät suhtautua tähän lievään kirkolliseen väritykseen? Asiakaskohderyhmän tarkempi valinta olisi ehkä ollut eduksi otteen syvenemiselle.

\section{Seurakunnissa ollaan}

parhaillaan siirtymässä vanhasta hallinnollisesta kirjanpidosta lähemmäs yritysten kirjanpitoa ja laskentatointa. ResurssiReppu ei käsittele raharesurssia ja sen roolia. Laskentatoimen uudistusta markkinoidaan kirkossa tulosajattelun viitetehyksessä. Sitä kavahtavat ovat jo näkevinään nurkan takana vaanivan uusliberalistisen markkinaajattelun hahmon. Ehkä se sopii hyvinkin kirjassa tarjottavaan "markkinaherkkään toimintaan". Toiminnan ja talouden uusi integraatio seurakunnissa tarjoaa sekä mahdollisuuksia että mahdottomuuksia myös konsulteille.
Repun työskentelyote lähtee yksilöstä tiimiin ja yhteisöön päin. Usko yksilöön on vahva, usko tiimiin ehkä vielä vahvempi. Toteamus, että jokaisella työntekijällä on oikeus kuulua tiimiin, jossa hän saa käsitellä omaan työhönsä liittyviä asioita, kuullostaa vanhan ryhmäkorosteisen ihmissuhdekoulukunnan uudelta tulemiselta. Ryhmän/tiimin ymmärtämisessä painottuvat enemmän humanistisen psykologian kuin dynaamisen psykologian tai systeemisen ajattelun näkökulmat. Tiimin toimivuutta arvioidaan ja kehitetään kolmella tasolla: tehtävän suorittaminen, tiimin sisäinen toimivuus ja työntekijöiden hyvinvointi. Tehtävän haastavuudella on keskeinen merkitys tiimin toimivuudelle.

Työskentelyn etenemismalli on saanut vaikutteita ns. toiminnallisista menetelmistä, joihin kuuluu esim. draamatyöskentely. Kunkin istunnon aluksi on "lämmittely", jonka tehtävänä on mielenkiinnon herättäminen ja suuntaaminen käsiteltävään strategisen suunnittelun prosessin kohtaan tai tiimin toimivuuden tasoon. Tematiikkaa lähestytään siihen liittyvistä kokemuksista, mielikuvista tai toiveista. Toiseksi siirrytään nykytilan tutkimiseen. Millaisia kokemuksia, havaintoja ja käsityksiä osallistujilla on tilanteesta? Mikä on tyydyttävällä kannalla? Missä on pulmia? Mitä on tarpeen muuttaa? Kolmannessa vaiheessa muutostyöskentelyssä etsitään ideoita ja mahdollisuuksia toivotun muutoksen suuntaan. Neljännessä vaiheessa kootaan tulokset ja tehdään mahdollisia sopimuksia. 


\section{ResurssiReppu hylkää} vanhan tavoitekeskeisen ja skenarioihin perustuvan strategisen ajattelun. "Tulevaisuutta ei tarvitse ennustaa." Etenemisen tapa on inkrementalistinen ja asiakaslähtöinen. Oleellista ei ole tulevaisuus ja tavoitteiden asettaminen, vaan sellaisen suunnitteluprosessin ylläpitäminen, joka toistuvasti tarkistaa suuntaa asiakkaan tilanteen ja työyhteisön vahvuuksien pohjalta. Olisiko tässä näkyvissä uudenlaiseen strategiseen paradigmaan pyrkimistä? Maa- ilmalla puhutaan siirtymisestä pois newtonilaisesta maailman hahmottamisesta kaaosteorian ja kompleksisuusteorian suuntaan. Ennustettavuus ja vakaus eivät ole enää tavoitteinakaan, pikemminkin kaaoksen ja järjestyksen integraatio tai rajallinen epävakaus.

Kirkollisesta maailmasta mieleen tulee jonkinlaisena analogiana Saksan evankelisten kirkkojen BrŸ cken bauen/Sillan rakentaminen - kehittämisohjelma. Se rakentaa projekteja, joissa toimitaan yhteistyössä seurakuntalaisten kanssa, parannetaan vuorovaikutusta, kehitetään seurakunnan toimintoja ja kohotetaan kirkon imagoa.

\section{ResurssiReppu herättää} ajatuksia ja synnyttää varmasti toimintaakin. Ehkä se parhaimmillaan pystyy yhdistämään mahdottomilta tuntuvia asioita, myös ajattelemisen ja tekemisen.

Timo Totro 